\title{
2006-2390: TRANSFORMING COLLEGE TEACHING COURSES INTO AUTHENTIC EXPERIENCES: LEARNING THROUGH DIVERSITY
}

\section{Sandra Courter, University of Wisconsin-Madison}

Sandra Shaw Courter teaches technical communication courses in the College of Engineering. As director of the Engineering Learning Center, she also coordinates professional development experiences for graduate students, staff, and faculty. She has been involved with several NSF proposal. First, as a member of the management team for the NSF Center for Integration of Research, Teaching, and Learning (CIRTL), Courter is responsible with a multi-disciplinary team for developing and teaching a course for graduate students on teaching science and engineering. Second, as a member of the management team for the Foundation Coalition at UW-Madison, she completed an on-line professional development program for twenty faculty from ten institutions.

\section{Joan Kwako, University of Wisconsin-Madison}

Joan Kwako recently earned her PhD in math education and will begin a tenure-track position in January at the University of Wisconsin - Duluth. She helped design and is currently teaching the course on which this paper is based.

\section{John Wright, University of Wisconsin-Madison}

John Wright is a professor of chemistry who helped design and teach two semesters of the course on which this paper is based. Former chair of the chemistry department, he is an innovative scholar. As such, he was instrumental in two national initiatives, New Traditions and the National Institute for Science Education. Now, he is with the Center for the Integration of Research, Teaching, and Learning CIRTL).

\section{Deanna Byrnes, Lawrence University}

Deanna Byrnes recently earned her PhD in zoology from the University of Wisconsin-Madison and is now a post doctoral candidate at Lawrence University where she is teaching science courses. While a graduate student at UW, she was the evaluation liaison for the college classroom team.

\section{Thatcher Root, University of Wisconsin-Madison}

Thatcher Root is a professor in the Department of Chemical and Biological Engineering. He currently is teaching the college classroom course for the first time. He is piloting the course portfolio that has evolved out of the first two versions of the course and his insights will be important as other teach the course in the future. He is involved in other innovative curricular issues plus is the ABET representative for his department.

\section{Clif Conrad, University of Wisconsin-Madison}

Clif Conrad is a professor in the School of Education, Department of Educational Leadership and Policy Development. He serves on the CIRTL college classroom team and has taught a two-week version of the course for the last three summers. 


\title{
Transforming College Teaching Courses into Authentic Experiences: Learning through Diversity
}

\begin{abstract}
Authentic achievement requires learners to "engage in disciplined inquiry to produce knowledge that has value in their lives beyond simply proving their competence." (Newmann, 1991) While college teaching courses provide an important role in preparing future faculty in STEM disciplines, a more authentic experience was the goal of one already successful course at the University of Wisconsin-Madison. Similar to other courses across the nation, students write a teaching philosophy, design a syllabus and learning plans, and complete a micro-teaching experience. While the micro-teaching experience is continually ranked as the most valuable, the instructors experimented with making the micro-teaching more authentic. In so doing, they piloted a "micro-course" in which students identified real students, rather than their peers, to teach. The unique components to the approach involved both the teaching-as-research model and the authentic achievement model.
\end{abstract}

The microcourse provided the context for potentially rich conversations about teaching and learning and, therefore, for learning itself. However, results of the pilot indicated that the authentic microcourse experience was not as significant as the instructors had assumed. Rather, the components of diversity, learning community, and teaching-asresearch were central to student learning; the basic micro-teaching experience returns as the authentic learning experience central to the course.

This paper describes the microcourse, an innovative approach to micro-teaching, the experience of students in the pilot of this innovation, and results from this "teaching as research" experiment. This research approach to microteaching provided an opportunity to try out different teaching methods and strategies for engaging learners; learning through diversity remains key to authentic experiences.

\section{Background}

Designed especially for graduate students in science, technology, engineering, and mathematics (STEM) disciplines, "Teaching Science and Engineering" provides a forum in which to discuss issues of learning, teaching, and assessment through the lens of "teaching-as-research." We define "teaching-as-research" as "a deliberate, systematic, and reflective use of research methods to develop and implement teaching practices that advance the learning experiences and learning outcomes of students as well as teachers." The graduate course is designed to promote the development of those skills and habits-ofmind, along with the knowledge base associated with high-quality teaching, learning, and assessment. Within the graduate course, students participate in a micro-course, an innovative adaptation of the traditional micro-teaching experience. The unique components to our approach are both the teaching-as-research model and the authentic achievement model. 


\section{Authentic Assessment}

Authentic projects involve specific content and human interactions that promote disciplined inquiry, also known as substantive conversation. In substantive conversation, each person is trying to express a point of view, to understand why others have their viewpoints, or to arrive at a solution to a problem that neither has previously is the most difficult. Four conditions are essential for authentic professional development: collaboration, access to tools and resources, discretion and ownership, and flexible use of time. According to Newmann, "substantive conversation is the key. It provides the crucible for practice, for seeking new knowledge that relates to the problem at hand, and for trial, feedback, and revision. In short, substantive conversation forces us to transform basic knowledge into applied, integrated knowledge." [1]

Authentic assessment has been the norm for the course since its beginning as a central component in the Delta Program [2]; however, the introduction of the micro-course is an "experiment" to make the traditional micro-teaching experience even more "real" or more authentic. For example, since its beginning, students have written and reviewed learning plans, assessment strategies, and a teaching and learning philosophy. In fall, 2004, we piloted the micro-course as an authentic assessment experience. Our hypothesis was that a microcourse would give students a more authentic teaching experience and, therefore, be more effective than a traditional micro-teaching experience.

We invited students to define the microcourse. For example, they could establish an undergraduate "boot camp" for undergraduates who are motivated to either learn material at greater depth in their discipline or undergraduates who wanted more experience in applying the fundamentals of a course to their discipline. The microcourse could be part of their teaching assistant responsibilities (if it is compatible with the course instructor's guidelines). Whatever direction they chose, it must provide an opportunity to try out different teaching and learning strategies and gain first hand experience with how to structure an active learning environment. In keeping with the Teaching as Research philosophy, their microteaching strategies must include the perspective of the research literature for teaching in your discipline. The strategies must include assessment methods that provide formative and summative assessment of the group's learning as well as feedback for individuals in their group about their command of the material.

\section{Teaching-as-Research}

Just as research should be a collaborative activity, so should teaching as research. It was important to have someone with whom to collaborate as students planned and implemented their microcourse. Students were paired as peer partners and faculty partners. The entire microcourse experience was designed to replicate a genuine research experience. Students were encouraged to identify a course and its relevant concepts and apply research methods from their STEM discipline to examine a real course with real students. In a similar way, we as faculty for the course followed the same process. This process serves as an example of the teaching-as-research (TAR) process:

Step one is to frame and define the problem. The context was the Delta College Classroom Course. The problem was how to build confidence in designing and 
implementing a learning plan. The research question followed: What learning experience will help strengthen students' confidence in designing and implementing a learning plan? Step two is to explore and construct a knowledge base including conducting a literature search, reflecting on past experiences, and investigating peers' and students' perspectives. Step three is to hypothesize and design learning experience: An authentic teaching experience will help strengthen students' confidence in designing and implementing a learning plan including multiple assessment strategies. Step four is to implement and adapt teaching practice as outlined in the learning plan. Step five is to test the hypothesis by gathering data as identified in the learning plan. Data gathering instruments identified included

-Pre and post surveys

-Authentic assessment (teaching and learning philosophy and micro-course)

-Focus group discussion

-SALGains on-line survey

Finally, step six is to reflect and improve continuously (use data). This "closes the loop" and fosters "teaching-for-learning."

The syllabus outlined formative assessment measures to answer a variety of questions. For example, what strategy would be most effective for helping students learn a specific concept in your discipline? How will you know? Have others had success with specific methods? If so, under what conditions? With what kinds of students? What research exists to demonstrate these results? What assessment technique/s would help you know that your students understand the concepts? What worked? What didn't? What revisions are appropriate? How successful was the re-design? What questions will you ask your peers as they observe your microteaching experience? The hope was to view classrooms as sites for ongoing research into teaching and to improve teaching to increase students' opportunities and potential for learning.

\section{Overview of Achievements and Challenges}

Identification of our significant accomplishments and challenges following fall 2003 and summer 2004 result from observations, students' artifacts, and a multiple approach to assessment of learning.

Achievements

- Participants demonstrated an understanding of teaching-as-research and the ability to apply a wide rage of assessment practices, learning theories, and teaching practices.

- Participants used concepts such as formative assessment, best practices, an absolute grading scale, and objectives in their micro-teaching and stated that they planned to use these in their future teaching as well.

- Participants rated the class as helping a great deal in areas such as developing their strengths as a teacher, their ability to self-reflect, their ability to teach and assess, and their awareness of the diversity of their students.

- Both the participants and the instructors represented diverse populations including gender, disciplines, positions, experience, and learning styles.

- The course curriculum, teaching and learning philosophy, and micro-teaching were "authentic assessment" measures; that is the assignments met the criteria for 
authentic achievement: construction of knowledge, disciplined inquiry, and value beyond school.

- Practical real-world learning encouraged participants to seek out other professional development opportunities especially those sponsored by the Delta learning community.

\section{Challenges}

- Being explicit about both diversity and learning community concepts is important; for example, students often did not recognize that they were both part of a learning community within the class and designers of learning communities as they developed a learning plan and curriculum.

- Students from diverse disciplines and ethnic backgrounds bring insights that help everyone learn; over ten disciplines and four minority groups were represented in our classes; however, African American and Hispanic students were not represented at all.

- Providing a more authentic learning experience with undergraduates in a real course will allow students to practice the theories more directly.

- Engaging more faculty in reflective practice and with graduate students' professional development needs attention.

\section{Proposed Changes}

To address the challenges, we envision integrating design projects into the course. For each project, a team of participants will have the opportunity to work on an existing undergraduate course to enhance students' learning in that course. Participants will work with the faculty associated with the course to review the course design, assess student learning, and make improvements throughout the semester. They will meet regularly with the faculty team to identify questions about the undergraduate students' learning, gather and analyze evidence, build on work of others, reflect on findings, and finally go public with tools or lessons learned. In collaboration with the faculty of both the College Classroom course and the undergraduate project course, students will take responsibility for this "teaching-as-research" experience to enhance student learning and will identify and complete "micro-teaching experiences" within the design project. Their systematic inquiry and activities may include designing and assessing a classroom assessment technique, an exam, a writing assignment, a rubric, or a different approach to teach a specific concept. During this next year, we envision incorporating three or four undergraduate courses as the "curriculum improvement projects," as these design projects may be called. We hypothesize that this experience will help participants develop more authentic and diverse learning communities with multiple perspectives and, therefore, engage all participants in reflective practice and mutual respect for and involvement in professional development activities for all.

\section{Rationale for Micro-Course Research}

After the first year and analysis of assessment data, faculty identified two questions that led to the micro-course as a more authentic learning experience for students. 
- How might students gain a more authentic learning experience in which they could experience a real class with real students during the same time they are participating in the college classroom course?

- How can we engage more faculty through intentional modifications to the course? To address the first two questions, we designed an option within the college classroom experience not only to engage more STEM faculty in the teaching and learning experience, but also provide students with a more authentic learning experience with a "project-based" course in which they can more effectively bridge the gap between theory and practice.

We integrated design projects into the course. For each project, a team of students had the opportunity to work on an existing undergraduate course to enhance students' learning in that course. Students will work with the faculty associated with the course to review the course design, assess student learning, and make improvements throughout the semester. All students will work on these design projects. However, students who enroll for three credits will provide leadership and documentation. All students will meet regularly with the faculty team to identify questions about the students' learning, gather and analyze evidence, build on work of others, reflect on findings, and finally go public with tools or lessons learned. In collaboration with the faculty of both the college classroom course and the undergraduate project course, students will take responsibility for this teachingas-research experience to enhance student learning and will identify and complete "micro-teaching experiences" within the design project. Their systematic inquiry and activities may include designing and assessing a classroom assessment technique, an exam, a writing assignment, a rubric, or a different approach to teach a specific concept. During this next year, we envision incorporating three or four undergraduate courses as the "curriculum improvement projects," as these design projects may be called.

We investigated a variety of learning experiences including the model of the School of Education (SOE) methods course in which students are aligned with a real class at the same time they are enrolled in a methods class; that is, education students participate in a SOE methods course while they are "student teaching" in an area K-12 classroom. Similarly, we envisioned that the college classroom course would incorporate one or both of these two "project-based" models:

1. a model similar to the School of Business (SOB) and Industrial Engineering (IE) quality improvement courses in which students develop the hands-on practical ability to manage the improvement of any process through just-intime learning teams.

2. a model in which a graduate student is also a teaching assistant in a concurrent course and will work with the faculty team.

The project-based course is not new to science, technology, engineering, mathematics and business. Business Operations and Information Management 770: Introduction to Quality and Productivity Improvement and Industrial Engineering 575 Introduction to Quality Engineering are two graduate courses. Engineering Professional Development 160: Introduction to Engineering is a highly acclaimed course for first-year students and is based on real-world projects submitted by real clients. All these examples have 
developed successful models through a rigorous assessment process similar to "teaching as research" which will be central to this component of the course.

In both models, students in EPD654: Teaching Science and Engineering (the college classroom course) would be aligned with real "project teams." Following the SOB and IE models, we can envision identifying three or four undergraduate courses and their respective faculty as an "authentic learning project." They would meet regularly with the course faculty team, design and implement the research plan, collect and analyze the results, work with the team to identify conclusions, recommendations for further work, and finally, submit an abstract for one conference, journal, forum, workshop, or other dissemination venue to "go public" with the project.

Identification of the courses could be either from the faculty or from the students. For example, a few engineering faculty are already considering their courses for this pilot. An engineering faculty person has had great success when students identify projects, so graduate students could propose a course as well. Graduate students who wanted to propose their teaching assistant position as the "project" for this component would need to gain their faculty support to work as a team and submit a proposal for their course. In all cases, a course proposal process would be important to establish.

\section{Assessment}

The assessment of activities included the authentic learning experiences (curriculum, microteaching, teaching philosophy, and response papers), Student Assessment of Learning Gains (SALGains), peer-review focus groups on the last class day, and pre- and post-surveys. Our assessment plan is based on the concept of authentic achievement as defined by Wehlage, Newmann, \& Secada (1996). The three criteria for authentic achievement are construction of knowledge, disciplined inquiry, and value beyond school. The assignments (microteaching, curriculum design, teaching and learning philosophy) involve the construction of knowledge based on disciplined inquiry. The three main features of disciplined inquiry are:

- Using prior knowledge

- Striving for in-depth understanding rather than superficial awareness

- Expressing one's ideas and findings through elaborated communication (adapted from the School of Education, University of Wisconsin, electronic portfolio website, http://careers.education.wisc.edu/epcsonline/public/help/fromPortfolios.cfm

In the course curriculum, teaching and learning philosophy, and micro-teaching experiences, students build on their prior knowledge of their discipline and teaching and learning, demonstrate in-depth understanding by using their prior knowledge to "facilitate complex understanding of discrete problems," and communicate their understandings in effectively designed products that are of value in their professional careers. We encouraged participants to place these products with corresponding reflections into a portfolio; the portfolio process is also an assessment of authentic achievement as defined above. According to the definition of elaborated communication, "If students learn to communicate in elaborate forms, they will be better able to construct knowledge, achieve in-depth understanding, and express their intellectual accomplishment more effectively." 
See Appendix A for our College Classroom Team Evaluation and Assessment Plan; it includes both our objectives from our strategic plan and the evidence. See Appendices B-D for the pre- and post-surveys and summary as well as the Student Assessment of Learning Gains (SALGains).

\section{Key Evaluation Questions}

1. To what extent did the students meet the course learning objectives?

2. What learning activities were significant in contributing to student learning and growth specifically as a professional in the academic community?

3. In what areas did the students demonstrate significant understanding of STEM teaching and learning issues? How do we know this?

4. What learning experiences were most significant? What ones might be more significant than the ones in the current syllabi?

\section{Analysis}

Summative assessment measures included a pre and post survey, observations, a focus group discussion with outside facilitators, and the on-line survey through the Student Assessment of Learning Gains (SALG). SALG data show that peer reviews, microteaching, and teaching and learning philosophies ranked lowest during the fall, 2004 course when we were experimenting with the micro-course. The Figure, Comparison of Authentic Assessments across All Terms, shows that Fall, 2004 (Series 1) ranks the lowest of all fours terms for which data was available. Series 2 is summer 2005; series 4 is summer 2004; and series 5 is fall 2003. From this data, summers rank higher than semester long courses and the experiment with the micro-course ranked lowest of all terms. 


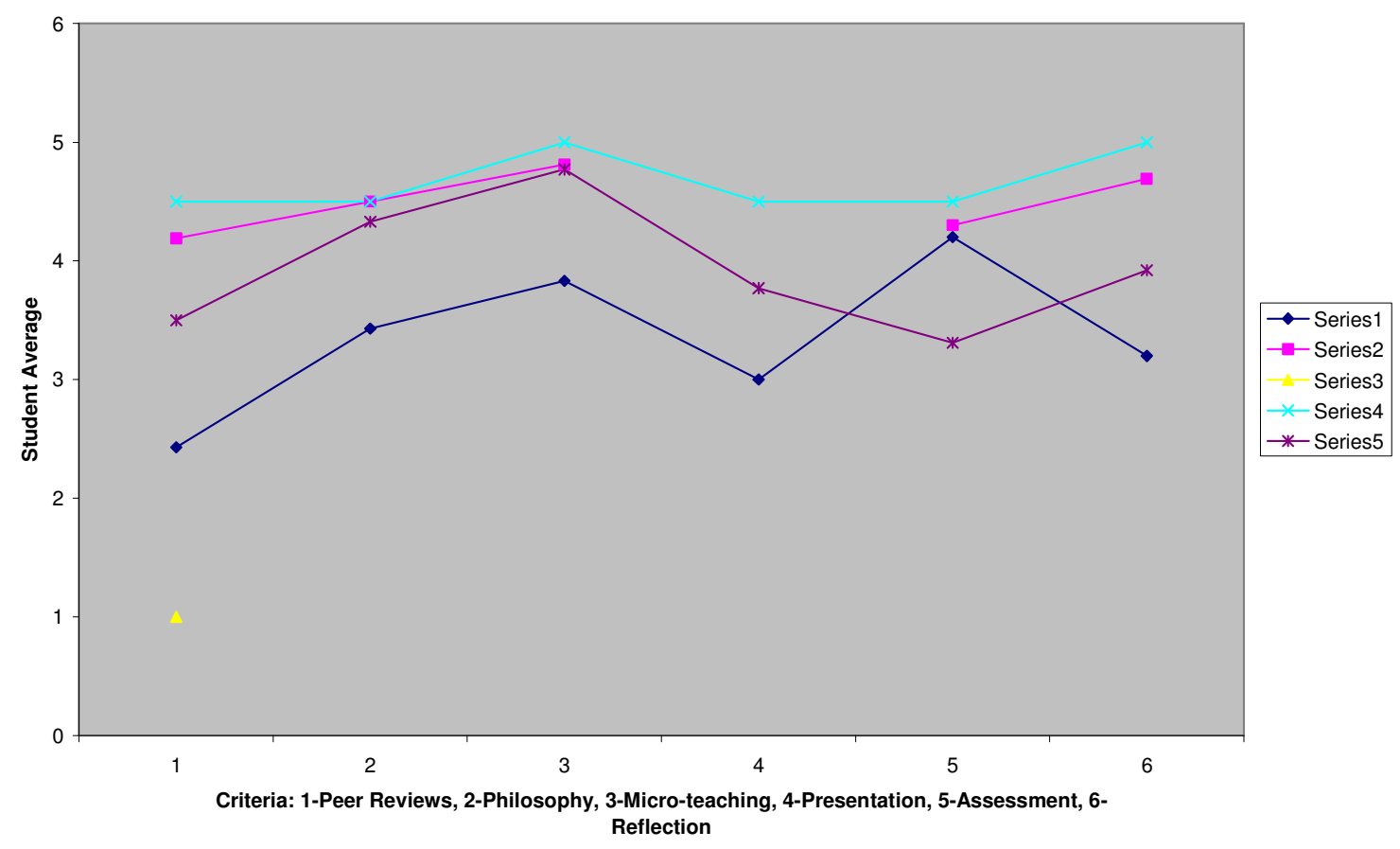

Comments from students on the SALG give context to the data that appear in the line graph. More comments for fall, 2003 and summer, 2004 are in Appendix D.

Fall, 2003

I love the micro-teaching idea. I don't feel that I gained as much from writing the teaching and learning philosophy as I could have. I think it would be better if I had more teaching experience.

I deeply appreciate the micro-teaching experience and Eric Mazur's presentation. It was wonderful hearing him and then spending the entire semester implementing his advice.

Fall, 2004

I felt the course was a bit "loose." I think my concerns centered around the microcourse. The microcourse is a great idea, in theory. The main problem being that you might have been better off to tone down your expectations (it was absurd request for many of us to find a group of students to participate AND do ten lectures)...I think the peer to peer groups could really work. I learned as much from watching the others in my group (or more) than I did from teaching. Plus, if a comfortable enough community could have been built - which it really didn't in our group, then the opportunity for feedback (assessment) is huge. I mean honest humble feedback. Overall, a good experience, but I'll bet it is much better the next time. We are all learning though this process. 
Summer 2005

The micro-teaching experience was the highlight of the course.

The practical teaching experience and being about to watch and critique myself was by far the most useful aspect of the class.

I learned more from the activities that we did such as microteaching and writing my teaching philosophy than I did in discussing some of the articles for hours.

[The micro-teaching unit] was a fabulous activity and really forced me to contemplate a teaching approach for learning - and to be prepared to get feedback from people - the videotaping and reflection were critical elements.

But still one person described the experience in a way that prompted us to experiment with the micro-teaching in the first place.

The microteaching activity was my first opportunity to practice designing and executing a learning plan - while it was very beneficial exercise, under the circumstances (15 minutes, mix of engineering/non-engineering backgrounds) I'm not sure how well it prepared me for an environment more like the ones I would actually teach in.

\section{Results and Conclusions}

The evidence helps us answer the key evaluation questions listed above. First, results show that students met the course learning objectives. Second, students reported in the SALG survey that the group discussions, peer reviews, teaching and learning philosophy examples and workshop, and the micro-teaching experience were significant in contributing to their learning and growth specifically as a professional in the academic community. Third, in the areas of assessment and teaching-as- research, students demonstrated significant understanding of STEM teaching and learning issues. This was evident in their learning plans, the improvements they made from one draft to another and from their peers' comments in the micro-teaching experience. Fourth, the microteaching experience was identified by most students as the most significant learning experience; this is important to know since the time-commitment to this experience is considerable. The experiment during fall, 2005 to replace the in-class micro-teaching with the micro-course resulted in a less than satisfactory experience for both students and faculty. So the hypothesis that "real" teaching experiences in "real" classrooms with undergraduate students was not an effective strategy in this course. Fifth, assessment instruments that are important to this learning experience are the authentic assessments (teaching and learning philosophy, curriculum, and the micro-teaching), the Student Assessment of Learning Gains (SALG) survey, and the pre-and post-surveys. 


\section{Recommendations}

We will use the micro-teaching learning experience and not the micro-course.

We will continue to rely on

- diverse, authentic assessment measures including the teaching and learning plan, the micro-teaching experience, and the curriculum design,

- pre and post surveys,

- peer review of teaching focus group at the end of the semester, and

- focus group with faculty involved in the "authentic learning projects."

These conclusions will expand the knowledge base for future endeavors as well as inform the design for the fall, 2006 course. A diversity of assessment strategies help us continuously improve the course for our diverse students.

Designing learning experiences is at the heart of the TAR process. Preliminary conclusions include returning to a basic micro-teaching experience, reserving an authentic experience for after the basics, and being more explicit about building learning community. Learning outcomes are key! The continuous nature of TAR challenges us to reflect, invites us to become learners, and helps us claim continuous responsibility for the learning of all our students.

\section{References}

[1] Newmann, Fred and M. Linking Restructuring to Authentic Student Achievement. pp. 458-463. February, 1991.

[2] Delta Program in Research, Teaching and Learning is the implementation of the Center for the Integration of Research, Teaching, and Learning (CIRTL) on the University of Wisconsin-Madison campus.

[3] Conrad, Clifton and D. Gupta. Teaching-as-Research: A Systematic Approach to Teaching-for-Learning. submitted for publication, 2005.

[4] Courter, Kwako, Wright, Conrad. The College Classroom Team Evaluation Report, April 2004 
APPENDICES

Appendix A Evaluation and Assessment Plan

Appendix B Student Assessment of Learning Gains Surveys

Appendix C Beginning and End-of-Semester Survey

Appendix D Assessment of Activities 


\section{APPENDIX A: EVALUATION AND ASSESSMENT PLAN}

\section{College Classroom Team - Evaluation/Assessment Plan}

\section{Objectives of the CIRILProfessional Development}

Program- taken fromStrategic Plan

\section{Forms of Evidence}

Authentic Assessment

- develop a discipline-specific curriculum that integrates active learning - learning plans - syllabi

- assessment - grading philosophy - microteaching peer review, revised microteaching - teaching philosophy

- response papers

Student Assessment of Leaming Gains (SALCains).

Students surveyed before and after about teaching and learning knowledge (selfreported).

Focus Group Discussion on last day of class.

Delta Participant Data Base (ERT)

Delta Focus Studies (ERT)

V. Provide multiple delivery formats and opportunities.

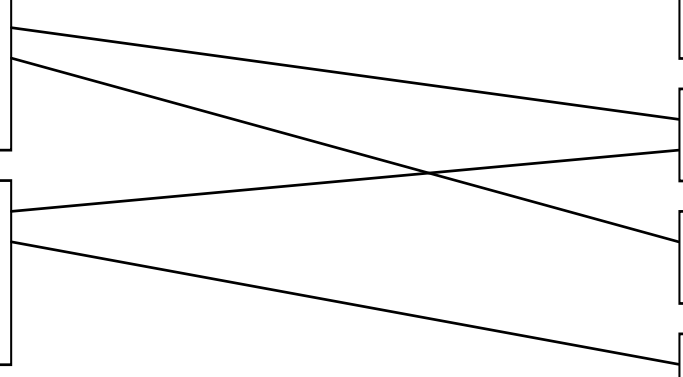

Summer 2004-PSUNewFac Workshop

Two-week summer/15-week semester

Mbdule Development? (evaluation-process and product?)

D.Bymes-CollegeClassroomEval Matrix.doc

$03 \mathrm{Feb} 2004$ 


\section{APPENDIX B: STUDENT ASSESSMENT OF LEARNING GAINS Student Assessment of Learning Gains}

Instrument

Teaching Science and Engineering University of Wisconsin - Madison: Engineering

Professional Development EPD654-01 Fall, 2003

Go to your List of Courses

$\underline{\log \text { Out }}$

Go to your Course Options

$<>$

Go back

Your students will see the questions as they appear on this page.

Instructions:

Check one value for each question on each scale. If the question is not applicable, check 'NA'. You may add a comment for any item in the text box at the end of the survey.

Q1: How much did each of the following aspects of the class help your learning?

\begin{tabular}{|c|c|c|c|c|c|c|}
\hline & NA & No help & $\begin{array}{c}\text { A } \\
\text { little } \\
\text { help }\end{array}$ & Moderate help & $\begin{array}{l}\text { Much } \\
\text { help }\end{array}$ & $\begin{array}{l}\text { Very } \\
\text { much } \\
\text { help }\end{array}$ \\
\hline $\begin{array}{l}\text { A. The way in which the material } \\
\text { was approached }\end{array}$ & $\mathrm{C}$ & $\mathrm{C}$ & C & $\mathbb{C}$ & $\mathrm{C}$ & $\mathbb{C}$ \\
\hline $\begin{array}{l}\text { B. How the class activities, labs, } \\
\text { reading, and assignments fit } \\
\text { together }\end{array}$ & C & $\mathbb{C}$ & $\mathbf{C}$ & $\mathbb{E}$ & C & $\mathbb{C}$ \\
\hline C. The pace at which we worked & C & C & $\mathbf{C}$ & C & C & $\mathbf{C}$ \\
\hline D. The class activities & NA & No help & \begin{tabular}{|c|} 
A \\
little \\
help
\end{tabular} & Moderate help & $\begin{array}{c}\text { Much } \\
\text { help }\end{array}$ & $\begin{array}{l}\text { Very } \\
\text { much } \\
\text { help }\end{array}$ \\
\hline 1. Readings & C & C & C & $\mathrm{C}$ & $\mathrm{C}$ & $\mathrm{C}$ \\
\hline 2. Group discussions & C & C & $\mathbf{C}$ & C & C & $\mathrm{C}$ \\
\hline $\begin{array}{l}\text { 3. Presentation and discussion of } \\
\text { assessment techniques }\end{array}$ & C & $\mathbf{C}$ & $\mathbf{C}$ & $\mathbb{C}$ & $\mathbb{C}$ & $\mathbf{C}$ \\
\hline 4. Information literacy lab (library) & C & C & $\mathbf{C}$ & $\mathbf{C}$ & C & $\mathrm{C}$ \\
\hline 5. Peer reviews & C & $\mathbf{C}$ & C & C & C & C \\
\hline 6. Rubric workshop & C & $\mathbf{C}$ & $\mathbf{C}$ & $\mathrm{C}$ & C & C \\
\hline
\end{tabular}




\begin{tabular}{|c|c|c|c|c|c|c|}
\hline $\begin{array}{l}\text { 7. Classroom Assessment Techniques } \\
\text { (CATs) }\end{array}$ & C & $\mathrm{C}$ & C & $\mathrm{C}$ & $\mathbf{C}$ & C \\
\hline $\begin{array}{l}\text { 8. Teaching and learning philosophy } \\
\text { examples and discussion }\end{array}$ & C & $\mathrm{C}$ & C & $\mathrm{C}$ & $\mathrm{C}$ & C \\
\hline $\begin{array}{l}\text { 9. Micro-teaching experience: } \\
\text { planning, doing, reflecting }\end{array}$ & $\mathrm{C}$ & $\mathrm{C}$ & C & $\mathrm{C}$ & $\mathbb{C}$ & C \\
\hline 10. Response papers & C & $\mathbf{C}$ & C & $\mathrm{C}$ & $\mathrm{C}$ & C \\
\hline $\begin{array}{l}\text { Please explain your ratings in the } \\
\text { space provided. }\end{array}$ & \multicolumn{6}{|c|}{$\begin{array}{ll} \\
\nabla\end{array}$} \\
\hline F. Resources & NA & No help & \begin{tabular}{|c|} 
A \\
little \\
help
\end{tabular} & Moderate help & $\begin{array}{l}\text { Much } \\
\text { help }\end{array}$ & $\begin{array}{l}\text { Very } \\
\text { much } \\
\text { help }\end{array}$ \\
\hline 1. Course homepage & C & C & C & C & C & $\mathbf{C}$ \\
\hline 2. On-line forums & C & C & C & $\mathbb{C}$ & $\mathbb{C}$ & $\mathrm{C}$ \\
\hline 3. Guiding questions for readings & $\mathrm{C}$ & $\mathbf{C}$ & C & C & $\mathbb{C}$ & $\mathrm{C}$ \\
\hline 4. Electronic library reserves & C & $\mathbf{C}$ & C & C & $\mathbf{C}$ & $\mathbf{C}$ \\
\hline $\begin{array}{l}\text { Please explain your ratings in the } \\
\text { space provided. }\end{array}$ & 1 & & & $\begin{array}{l} \pm \\
\end{array}$ & & \\
\hline $\begin{array}{l}\text { G. The information we were given } \\
\text { about }\end{array}$ & NA & No help & \begin{tabular}{|c|} 
A \\
little \\
help \\
\end{tabular} & Moderate help & $\begin{array}{l}\text { Much } \\
\text { help }\end{array}$ & $\begin{array}{l}\text { Very } \\
\text { much } \\
\text { help }\end{array}$ \\
\hline $\begin{array}{l}\text { 1. Learning plans and course } \\
\text { curriculum }\end{array}$ & C & $\mathrm{C}$ & C & C & $\mathbf{C}$ & C \\
\hline 2. Weekly learning plan & C & C & C & $\mathrm{C}$ & $\mathbf{C}$ & $\mathbf{C}$ \\
\hline 3. Assignments in general & C & C & C & C & C & C \\
\hline 4. Course expectations in general & C & C & C & $\mathrm{C}$ & $\mathbf{C}$ & $\mathrm{C}$ \\
\hline $\begin{array}{l}\text { Please explain your ratings in the } \\
\text { space provided. }\end{array}$ & 4 & & & $\begin{array}{l}\Delta \\
7\end{array}$ & & \\
\hline H. Individual support as a learner & NA & No help & \begin{tabular}{|c|} 
A \\
little \\
help
\end{tabular} & Moderate help & $\begin{array}{l}\text { Much } \\
\text { help }\end{array}$ & $\begin{array}{l}\text { Very } \\
\text { much } \\
\text { help }\end{array}$ \\
\hline 1. Contact with teachers (teacher- & $\mathrm{C}$ & $\mathbf{C}$ & C & C & C & $\mathrm{C}$ \\
\hline
\end{tabular}




\begin{tabular}{|c|c|c|c|c|c|c|}
\hline \multicolumn{7}{|l|}{ learner interaction) } \\
\hline $\begin{array}{l}\text { 2. Contact with peers (learner-learner } \\
\text { interaction) }\end{array}$ & $\mathrm{C}$ & $\mathrm{C}$ & $\mathbf{C}$ & $\mathrm{C}$ & $\mathrm{C}$ & C \\
\hline 3. Instructor feedback & C & C & C & $\mathbb{C}$ & C & C \\
\hline 4. Peer feedback & $\mathrm{C}$ & $\mathbf{C}$ & $\mathrm{C}$ & $\mathrm{C}$ & C & C \\
\hline $\begin{array}{l}\text { Please explain your ratings in the } \\
\text { space provided. }\end{array}$ & $|1|$ & & & 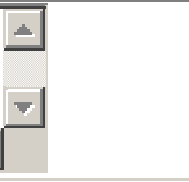 & & \\
\hline $\begin{array}{l}\text { K. The way this class was taught } \\
\text { overall }\end{array}$ & C & $\mathrm{C}$ & C & C & $\mathrm{C}$ & $\mathrm{C}$ \\
\hline \multicolumn{7}{|c|}{$\begin{array}{l}\text { Q2: As a result of your work in this class, how well do you think that you now } \\
\text { understand each of the following? }\end{array}$} \\
\hline & NA & Not at all & $\begin{array}{c}\text { A } \\
\text { little }\end{array}$ & Somewhat & A lot & $\begin{array}{c}\text { A great } \\
\text { deal }\end{array}$ \\
\hline $\begin{array}{l}\text { 1. Your approach to teaching and } \\
\text { learning (your philosophy) }\end{array}$ & $\mathrm{C}$ & $\mathbf{C}$ & $\mathrm{C}$ & $\mathbf{C}$ & $\mathbf{C}$ & C \\
\hline $\begin{array}{l}\text { 2. Your strengths as a teacher and } \\
\text { learner }\end{array}$ & $\mathrm{C}$ & $\mathrm{C}$ & C & $\mathrm{C}$ & $\mathrm{C}$ & $\mathrm{C}$ \\
\hline $\begin{array}{l}\text { 3. Your opportunities as a teacher and } \\
\text { learner }\end{array}$ & $\mathrm{C}$ & C & C & C & $\mathbb{C}$ & C \\
\hline 4. Teaching as research & $\mathrm{C}$ & C & C & C & C & $\mathrm{C}$ \\
\hline 5. Learning community concept & C & C & $\mathrm{C}$ & $\mathrm{C}$ & $\mathrm{C}$ & $\mathrm{C}$ \\
\hline 6. Roles of assessment & C & C & C & C & C & C \\
\hline 7. Grading philosophy & C & C & $\mathrm{C}$ & C & C & C \\
\hline $\begin{array}{l}\text { Please explain your ratings in the } \\
\text { space provided. }\end{array}$ & $\mid$\begin{tabular}{|l|l|}
+1 \\
\end{tabular} & & & $\begin{array}{ll} \\
\end{array}$ & & \\
\hline \multicolumn{7}{|c|}{ Q3: How much has this class added to your skills in each of the following? } \\
\hline & NA & Nothing & $\begin{array}{c}\mathrm{A} \\
\text { little }\end{array}$ & Somewhat & A lot & $\begin{array}{c}\text { A great } \\
\text { deal }\end{array}$ \\
\hline 1. Peer reviews & C & $\mathrm{C}$ & C & $\mathrm{C}$ & $\mathrm{C}$ & $\mathbf{C}$ \\
\hline 2. Critical self-reflection as a teacher & C & C & C & C & C & C \\
\hline $\begin{array}{l}\text { 3. Curriculum design (content } \\
\text { including objectives, instruction } \\
\text { including learning activities, and } \\
\text { assessment) }\end{array}$ & C & $\mathrm{C}$ & C & C & $\mathbf{C}$ & $\mathrm{C}$ \\
\hline 4. Teaching & C & $\mathrm{C}$ & C & $\mathrm{C}$ & $\mathrm{C}$ & $\mathrm{C}$ \\
\hline 5. Assessment & C & $\mathbb{C}$ & C & $\mathbb{C}$ & 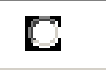 & $\mathbb{E}$ \\
\hline
\end{tabular}




\begin{tabular}{|c|c|c|c|c|c|c|}
\hline 6. Learning Plans & $\mathrm{C}$ & C & $\mathbf{C}$ & C & C & C \\
\hline $\begin{array}{l}\text { Please explain your ratings in the } \\
\text { space provided. }\end{array}$ & \multicolumn{6}{|c|}{ 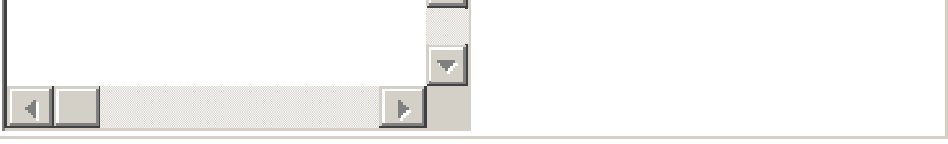 } \\
\hline \multicolumn{7}{|c|}{$\begin{array}{l}\text { Q4: To what extent did you make gains in any of the following as a result of what } \\
\text { you did in this class? }\end{array}$} \\
\hline & NA & Not at all & $\begin{array}{c}\mathrm{A} \\
\text { little }\end{array}$ & Somewhat & A lot & $\begin{array}{c}\text { A great } \\
\text { deal }\end{array}$ \\
\hline 1. Confidence in teaching & $\square$ & C & C & C & C & $\mathbf{C}$ \\
\hline $\begin{array}{l}\text { 2. Building inclusive learning } \\
\text { environments }\end{array}$ & $\mathbf{C}$ & $\mathbf{C}$ & $\mathbf{C}$ & $\mathbf{C}$ & C & $\mathbf{C}$ \\
\hline $\begin{array}{l}\text { 3. Enthusiasm for teaching and } \\
\text { learning in higher education }\end{array}$ & $\mathbf{C}$ & $\mathbf{C}$ & C & $\mathbf{C}$ & C & $\mathbf{C}$ \\
\hline $\begin{array}{l}\text { 4. Confidence in viewing my } \\
\text { classroom as a site for teaching-as- } \\
\text { research }\end{array}$ & $\mathbf{E}$ & $\mathbf{C}$ & $\mathbf{C}$ & $\mathbf{C}$ & $\mathbf{C}$ & $\mathbf{C}$ \\
\hline $\begin{array}{l}\text { Please explain your ratings in the } \\
\text { space provided. }\end{array}$ & A & & & & & \\
\hline \multicolumn{7}{|c|}{$\begin{array}{l}\text { Q5: How much of the following do you think you will remember and carry with you } \\
\text { into other classes or aspects of your life? }\end{array}$} \\
\hline & NA & Not at all & \begin{tabular}{|c|} 
A \\
little \\
\end{tabular} & Somewhat & A lot & $\begin{array}{c}\text { A great } \\
\text { deal }\end{array}$ \\
\hline $\begin{array}{l}\text { 1. Critical reflection and continuous } \\
\text { improvement }\end{array}$ & $\mathbf{C}$ & $\mathbf{C}$ & $\mathbf{C}$ & $\mathbf{C}$ & C & C \\
\hline 2. Peer review & $\mathbf{C}$ & $\mathbf{C}$ & $\mathbf{C}$ & $\mathbf{C}$ & $\mathbf{C}$ & $\mathbf{E}$ \\
\hline 3. Learning communities & $\mathbf{E}$ & $\mathbf{E}$ & $\mathbf{C}$ & $\mathbf{E}$ & $\mathbb{E}$ & $\mathbf{E}$ \\
\hline 4. Teaching as research & $\mathbf{E}$ & $\mathbf{E}$ & $\mathbf{C}$ & $\mathbf{E}$ & $\mathbf{E}$ & $\mathbf{C}$ \\
\hline 5. Active learning strategies & $\mathbf{E}$ & $\mathbf{E}$ & $\mathbf{C}$ & $\mathbf{C}$ & $\mathbf{E}$ & $\mathbf{C}$ \\
\hline 6. Group work & $\mathbf{C}$ & $\mathbf{E}$ & C & C & E & $\mathbf{E}$ \\
\hline 7. Best practices, in general & E & $\mathbf{C}$ & C & $\mathbb{C}$ & $\mathbf{C}$ & $\mathbf{C}$ \\
\hline 8. Assessment & E & $\mathbf{E}$ & $\mathbf{C}$ & C & E & $\mathrm{E}$ \\
\hline 9. Perspectives of students (diversity) & $\mathbf{C}$ & $\mathbf{E}$ & $\mathbf{C}$ & $\mathbf{C}$ & $\mathbf{C}$ & $\mathbf{C}$ \\
\hline 10. Inclusive learning environments & $\mathbf{E}$ & $\mathbf{E}$ & $\mathbf{C}$ & $\mathbf{E}$ & $\mathbf{E}$ & $\mathbf{E}$ \\
\hline
\end{tabular}


Please explain your ratings in the space provided.

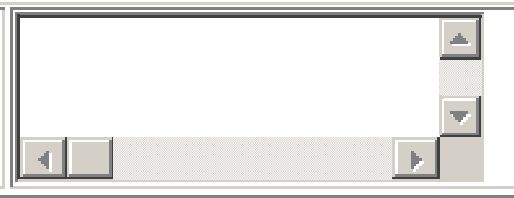

\section{Q6: Add comments below}

\section{$1 \square$}

This site was created with funding courtesy of the ExxonMobil Foundation and the following National Science Foundation-funded projects:

New Traditions (NT)

ChemLinks

ModularChemistry (MC2)

The National Institute for Science Education
The AAC\&U SENCER Institutes

Original Content Copyright (C1997 Elaine Seymour. All rights reserved. Your comments are welcome.

\section{Student Assessment of Learning Gains}

View Course Responses

Teaching Science and Engineering University of Wisconsin - Madison: Engineering Professional Development EPD654-01 Fall, 2003

Go to your List of Courses

$\underline{\log \text { Out }}$

Go to your Course Options

Go Back

\begin{tabular}{|c|c|c|c|c|c|c|c|c|c|c||}
\hline & NA & $\mathbf{1}$ & $\mathbf{2}$ & $\mathbf{3}$ & $\mathbf{4}$ & $\mathbf{5}$ & total & ave (stdev) & NR \\
\hline Q1A & $0 \%$ & $0 \%$ & $0 \%$ & $15 \%$ & $54 \%$ & $31 \%$ & 13 & $4.15(0.66)$ & 0 \\
\hline Q1B & $0 \%$ & $0 \%$ & $8 \%$ & $31 \%$ & $46 \%$ & $15 \%$ & 13 & $3.69(0.82)$ & 0 \\
\hline \hline Q1C & $0 \%$ & $0 \%$ & $0 \%$ & $38 \%$ & $46 \%$ & $15 \%$ & 13 & $3.77(0.7)$ & 0 \\
\hline \hline Q1D.1 & $0 \%$ & $8 \%$ & $23 \%$ & $23 \%$ & $46 \%$ & $0 \%$ & 13 & $3.08(1)$ & 0 \\
\hline \hline Q1D.2 & $0 \%$ & $0 \%$ & $0 \%$ & $25 \%$ & $42 \%$ & $33 \%$ & 12 & $4.08(0.76)$ & 1 \\
\hline \hline Q1D.3 & $0 \%$ & $8 \%$ & $8 \%$ & $15 \%$ & $38 \%$ & $31 \%$ & 13 & $3.77(1.19)$ & 0 \\
\hline \hline Q1D.4 & $0 \%$ & $8 \%$ & $46 \%$ & $38 \%$ & $8 \%$ & $0 \%$ & 13 & $2.46(0.75)$ & 0 \\
\hline \hline Q1D.5 & $8 \%$ & $0 \%$ & $15 \%$ & $23 \%$ & $46 \%$ & $8 \%$ & 13 & $3.5(0.87)$ & 0 \\
\hline \hline Q1D.6 & $0 \%$ & $15 \%$ & $8 \%$ & $46 \%$ & $23 \%$ & $8 \%$ & 13 & $3(1.11)$ & 0 \\
\hline Q1D.7 & $0 \%$ & $15 \%$ & $8 \%$ & $23 \%$ & $38 \%$ & $15 \%$ & 13 & $3.31(1.26)$ & 0 \\
\hline \hline Q1D.8 & $8 \%$ & $0 \%$ & $0 \%$ & $15 \%$ & $31 \%$ & $46 \%$ & 13 & $4.33(0.75)$ & 0 \\
\hline \hline Q1D.9 & $0 \%$ & $0 \%$ & $0 \%$ & $0 \%$ & $23 \%$ & $77 \%$ & 13 & $4.77(0.42)$ & 0 \\
\hline \hline Q1D.10 & $8 \%$ & $15 \%$ & $8 \%$ & $38 \%$ & $15 \%$ & $15 \%$ & 13 & $3.08(1.26)$ & 0 \\
\hline
\end{tabular}




\begin{tabular}{|c|c|c|c|c|c|c|c|c|c|}
\hline Q1F.1 & $0 \%$ & $0 \%$ & $8 \%$ & $38 \%$ & $38 \%$ & $15 \%$ & 13 & $3.62(0.84)$ & 0 \\
\hline Q1F.2 & $0 \%$ & $31 \%$ & $23 \%$ & $23 \%$ & $23 \%$ & $0 \%$ & 13 & $2.38(1.15)$ & 0 \\
\hline Q1F.3 & $0 \%$ & $15 \%$ & $15 \%$ & $31 \%$ & $15 \%$ & $23 \%$ & 13 & $3.15(1.35)$ & 0 \\
\hline Q1F.4 & $0 \%$ & $0 \%$ & $0 \%$ & $23 \%$ & $15 \%$ & $62 \%$ & 13 & $4.38(0.84)$ & 0 \\
\hline Q1G.1 & $0 \%$ & $0 \%$ & $15 \%$ & $31 \%$ & $23 \%$ & $31 \%$ & 13 & $3.69(1.07)$ & 0 \\
\hline Q1G.2 & $0 \%$ & $0 \%$ & $15 \%$ & $15 \%$ & $38 \%$ & $31 \%$ & 13 & $3.85(1.03)$ & 0 \\
\hline Q1G.3 & $0 \%$ & $0 \%$ & $23 \%$ & $23 \%$ & $46 \%$ & $8 \%$ & 13 & $3.38(0.92)$ & 0 \\
\hline Q1G.4 & $0 \%$ & $8 \%$ & $15 \%$ & $23 \%$ & $46 \%$ & $8 \%$ & 13 & $3.31(1.07)$ & 0 \\
\hline Q1H.1 & $0 \%$ & $0 \%$ & $0 \%$ & $23 \%$ & $38 \%$ & $38 \%$ & 13 & $4.15(0.77)$ & 0 \\
\hline Q1H.2 & $0 \%$ & $0 \%$ & $15 \%$ & $8 \%$ & $54 \%$ & $23 \%$ & 13 & $3.85(0.95)$ & 0 \\
\hline Q1H.3 & $0 \%$ & $0 \%$ & $0 \%$ & $23 \%$ & $15 \%$ & $62 \%$ & 13 & $4.38(0.84)$ & 0 \\
\hline Q1H.4 & $0 \%$ & $0 \%$ & $8 \%$ & $23 \%$ & $38 \%$ & $31 \%$ & 13 & $3.92(0.92)$ & 0 \\
\hline Q1K & $0 \%$ & $0 \%$ & $0 \%$ & $33 \%$ & $22 \%$ & $44 \%$ & 9 & $4.11(0.87)$ & 4 \\
\hline $\mathrm{Q} 2.1$ & $0 \%$ & $0 \%$ & $0 \%$ & $8 \%$ & $54 \%$ & $38 \%$ & 13 & $4.31(0.61)$ & 0 \\
\hline Q2.2 & $0 \%$ & $0 \%$ & $0 \%$ & $23 \%$ & $54 \%$ & $23 \%$ & 13 & $4(0.68)$ & 0 \\
\hline Q2.3 & $0 \%$ & $0 \%$ & $8 \%$ & $31 \%$ & $46 \%$ & $15 \%$ & 13 & $3.69(0.82)$ & 0 \\
\hline Q2.4 & $0 \%$ & $0 \%$ & $15 \%$ & $15 \%$ & $46 \%$ & $23 \%$ & 13 & $3.77(0.97)$ & 0 \\
\hline $\mathrm{Q} 2.5$ & $0 \%$ & $0 \%$ & $31 \%$ & $31 \%$ & $8 \%$ & $31 \%$ & 13 & $3.38(1.21)$ & 0 \\
\hline Q2.6 & $0 \%$ & $0 \%$ & $8 \%$ & $8 \%$ & $38 \%$ & $46 \%$ & 13 & $4.23(0.89)$ & 0 \\
\hline Q2.7 & $0 \%$ & $0 \%$ & $8 \%$ & $23 \%$ & $31 \%$ & $38 \%$ & 13 & $4(0.96)$ & 0 \\
\hline Q3.1 & $0 \%$ & $0 \%$ & $15 \%$ & $54 \%$ & $23 \%$ & $8 \%$ & 13 & $3.23(0.8)$ & 0 \\
\hline Q3.2 & $0 \%$ & $0 \%$ & $15 \%$ & $8 \%$ & $46 \%$ & $31 \%$ & 13 & $3.92(1)$ & 0 \\
\hline Q3.3 & $0 \%$ & $0 \%$ & $8 \%$ & $8 \%$ & $62 \%$ & $23 \%$ & 13 & $4(0.78)$ & 0 \\
\hline Q3.4 & $0 \%$ & $0 \%$ & $8 \%$ & $15 \%$ & $46 \%$ & $31 \%$ & 13 & $4(0.88)$ & 0 \\
\hline Q3.5 & $0 \%$ & $0 \%$ & $8 \%$ & $15 \%$ & $46 \%$ & $31 \%$ & 13 & $4(0.88)$ & 0 \\
\hline Q3.6 & $0 \%$ & $0 \%$ & $8 \%$ & $23 \%$ & $38 \%$ & $31 \%$ & 13 & $3.92(0.92)$ & 0 \\
\hline Q4.1 & $0 \%$ & $0 \%$ & $15 \%$ & $23 \%$ & $38 \%$ & $23 \%$ & 13 & $3.69(0.99)$ & 0 \\
\hline Q4.2 & $0 \%$ & $0 \%$ & $15 \%$ & $31 \%$ & $31 \%$ & $23 \%$ & 13 & $3.62(1)$ & 0 \\
\hline Q4.3 & $0 \%$ & $0 \%$ & $8 \%$ & $31 \%$ & $23 \%$ & $38 \%$ & 13 & $3.92(1)$ & 0 \\
\hline Q4.4 & $0 \%$ & $0 \%$ & $23 \%$ & $15 \%$ & $23 \%$ & $38 \%$ & 13 & $3.77(1.19)$ & 0 \\
\hline Q5.1 & $0 \%$ & $0 \%$ & $8 \%$ & $15 \%$ & $38 \%$ & $38 \%$ & 13 & $4.08(0.92)$ & 0 \\
\hline Q5.2 & $0 \%$ & $0 \%$ & $8 \%$ & $31 \%$ & $54 \%$ & $8 \%$ & 13 & $3.62(0.74)$ & 0 \\
\hline Q5.3 & $0 \%$ & $8 \%$ & $23 \%$ & $23 \%$ & $15 \%$ & $31 \%$ & 13 & $3.38(1.33)$ & 0 \\
\hline Q5.4 & $0 \%$ & $0 \%$ & $15 \%$ & $23 \%$ & $31 \%$ & $31 \%$ & 13 & $3.77(1.05)$ & 0 \\
\hline Q5.5 & $0 \%$ & $0 \%$ & $0 \%$ & $8 \%$ & $38 \%$ & $54 \%$ & 13 & $4.46(0.63)$ & 0 \\
\hline
\end{tabular}




\begin{tabular}{|c|c|c|c|c|c|c|c|c|c||}
\hline Q5.6 & $0 \%$ & $0 \%$ & $8 \%$ & $8 \%$ & $54 \%$ & $31 \%$ & 13 & $4.08(0.83)$ & 0 \\
\hline \hline Q5.7 & $8 \%$ & $0 \%$ & $0 \%$ & $15 \%$ & $54 \%$ & $23 \%$ & 13 & $4.08(0.64)$ & 0 \\
\hline \hline Q5.8 & $0 \%$ & $0 \%$ & $8 \%$ & $8 \%$ & $69 \%$ & $15 \%$ & 13 & $3.92(0.73)$ & 0 \\
\hline \hline Q5.9 & $0 \%$ & $0 \%$ & $8 \%$ & $15 \%$ & $46 \%$ & $31 \%$ & 13 & $4(0.88)$ & 0 \\
\hline \hline Q5.10 & $0 \%$ & $0 \%$ & $8 \%$ & $23 \%$ & $38 \%$ & $31 \%$ & 13 & $3.92(0.92)$ & 0 \\
\hline
\end{tabular}

This site was created with funding courtesy of the ExxonMobil Foundation and the following National Science Foundation-funded projects:

\begin{tabular}{|l|l|l|}
\hline \hline New Traditions (NT) & The National Institute for Science \\
\hline ModularChemistry (MC2) & $\underline{\text { Education }}$ & $\underline{\text { The AAC\&U SENCER }}$ \\
\hline \hline \multicolumn{2}{|c|}{ Original Content Copyright (C1997 Elaine Seymour. All rights reserved. Your comments are welcome. } \\
\hline \hline
\end{tabular}

\title{
Student Assessment of Learning Gains
}

Comments

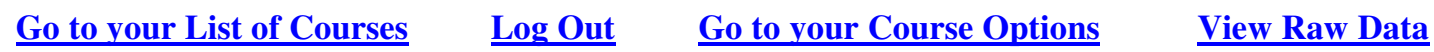

Go Back

Q1D. How much did each of the following aspects of the class help your learning? (The class activities)

I greatly enjoyed the reading assignments but often felt there wasn't enough time to discuss them. Also, I didn't find the peer reviews particularly helpful but I think that is more a function of who reviewed me then the actual notion of peer review. I did like the peer feedback at the end of microteaching though - that was great!

I love the microteaching idea. I don't feel I gained as much from writing the teaching and learning philosophy as I could have. I think it would be best if I had more experience teaching. The CATs were very creative and a wonderful way to gain new ideas for my classes. The readings were pretty helpful, but Eric Mazur was astounding! His talk really defined my experience in this course; I keep drawing ALL of the readings and discussions back to him. An excellent way to start the course!

In general, I though that there were too many things to do each week (readings *and* lesson plans *and* response papers). I think you shouldn't expect grad students to have more than 1-2 hours per week to devote to class.

I greatly appreciated the readings - a selection of informative articles on a variety of 
topics. Peer review of teaching and various assignments was also very helpful for me.

The class activities were very help and provided insight in the different aspects of teaching and learning

Learned a lot in the class, enjoyed myself as well. Found that the response papers were not very helpful as few people participated in the forum from which the response papers were based. Not a lot of additional insight was gained, over the small group discussions, from writing a response. The forum though, was a good idea and added additional insight and a good space to communicate with classmates, but the response paper just didnt do it for me. Also, class readings were really helpful but taxing at times and it was good that the instructors took this feedback and made appropriate adjustments.

The course activities were put together well, and overall were quite helpful. I did not learn much in the information literacy lab though.

I really liked it when instructors modeled the teaching-as-research approach. While most elements of the course were integrated into the whole, some were almost "afterthoughts," maybe because we ran out of time. I would have been interested in doing even more experimenting (teaching as research) myself).

\section{Q1F. How much did each of the following aspects of the class help your learning?} (Resources)

The resources very valuable

The web site was really great. It helped me figure out a lot about course logistics as well as related programs. I don't think many of the student groups used the on-line forum. For my group, it was just as easy to email around, and would have been perhaps more confusing to try to remember to check the website. If we would have had more of a focus on students as researchers (experimenters), the questions forum may have been more useful.

Sometimes I felt like we were being given too much information, which is most likely the case when you become an instructor sometimes, but as a student in this course, it often made it difficult to understand what was requested of the students.

I wish I had used the course home page more, I think the forums are a really good idea I just didn't often find the time to go look at them.

The course homepage could be cleaned up, updated more often, and organized a bit. I could never get the learning plans from the previous week, and if I lost my paper copy, I found it hard to know what to do for the next week. The on-line forums were also not very useful - I think our discussions in class were MUCH more insightful. I never really use forums in general though. The guiding questions for the reading were an excellent way to make us focus on the topics we were to discuss in class and they were very well presented. The electronic library reserves were also fantastic - I even sent a few of the more interesting articles to friends of mine. 


\section{Q1G. How much did each of the following aspects of the class help your learning? (The information we were given about)}

I did not always know what was due when. It changed, sometimes without being updated on the web site. Expectations for some of the assignments were not clear: the course curriculum in particular. I would have appreciated clearer organization of the course.

Sample papers and guidelines about the various aspects of planning a course were of great help when it came time to design my own course.

Overall, assignments were clear. When they weren't, instructors were flexible, so I was content. What I would have liked is to have seen the final teaching portfolio assignment during the first weeks of the semester. Perhaps it wasn't ready then - I know the rubrics weren't. It really helps me to see how all of my smaller tasks fit into the big picture.

We were often told about things at the last minute, and there frequently were only sketchy details about what was expected.

At times, what was expected for the course curriculum was a little unclear but I still found the whole thing to be an invaluable experience

I think it would be better if you had one list of ALL the assignments, their due dates, and what each entails to give out at the beginning of the course. As it stands, it was a little unorganized and I had trouble figuring out what I needed to work on next.

\section{Q1H. How much did each of the following aspects of the class help your learning? (Individual support as a learner)}

The classroom interactions were great and the class itself served as a model for how our classes should be run.

Didn't receive much feedback on teaching and learning philosophy or CV from peerswhat I did receive was helpful

I thought the time and energy the instructors put in to this class was fabulous. I got great feedback and wonderful comments that really helped me improve throughout the semester - thanks!

My experiences with instructors and peers was terrific - a critical part of the learning. Instructors did an outstanding job of helping me when confused and of facilitating learning with my peers. 


\section{Q2. As a result of your work in this class, how well do you think that you now understand each of the following?}

Learning is a humbling experience and the more I learn, the more I realize there's so much more I want to master. This course offered a great way to take some leaps forward.

I feel as though I have learned a great deal about the various learning practices and look forward to employing them.

I've learned a great deal as a result of this course in all of the above areas. I feel confident that I have a good basis to continue my learning in this area.

Before this class, I knew I wanted to teach but that was about all the thought I had given it, this course really helped me to clarify my views on teaching and learning and what I am looking for in a teaching position.

This class was a great help for me in deciding whether I would like to teach or not. I understand the teacher's role in the classroom much better, and it has even helped me out as a student in many of my classes! I don't really understand the opportunities available to me yet, but that's likely a result of not looking for a job at this point.

I don't feel as though I was exposed to lots of new ideas in this class.

\section{Q3. How much has this class added to your skills in each of the following?}

I really learned a lot in this course - I feel, as a result of this class, I understand all of these items "A great deal" better.

Q4. To what extent did you make gains in any of the following as a result of what you did in this class?

The course covered a lot and could really be split into two courses: one that focuses on course curriculum development and another that focuses on teaching as research. I learned a lot, and it's probably natural that I want a more in-depth, focused experience because I want to continue studying teaching and learning.

Q5. How much of the following do you think you will remember and carry with you into other classes or aspects of your life? 
While best practices were mentioned in the last few class meetings, I'm not sure I feel like I know when I was looking at them - what is a best practice?

I believe I will retain much of what was experienced in our class room and be able to employ it in future courses I teach.

What are "best practices?"

\section{Q6. Add comments below}

I think that this class would be easier to prepare for if it were earlier in the week (like Monday or Tuesday).

In general I enjoyed the class very much and found it very useful as it helps me improve my teaching and the provide me with different strategies I can implement towards successful teaching.

Great course. A definite necessity for any students looking to teach in the future.

Overall, I feel like I learned quite a bit in this course. I only really have one complaint, and I'm not really sure this is a very fair complaint. The assignments that we had generally seemed pretty useful and worthwhile. On the other hand, I thought that at times we had so many things due that I really couldn't take the time to do a very thoughtful job on everything. Consequently, I thought there were some occasions where I was not particularly pleased with the quality of the work that I turned in because I just didn't take as much time as I should have working on it. I guess I would have gotten more out of some of the assignments if I had been able to really think about them instead of needing to "move on" to work on the next assignment. But maybe I'm just whining a little more than I should about having to do a little work.

A very well run course, and one that I looked forward to every week. It could be a little better organized in respect to the assignments, but it was nonetheless quite well prepared. I deeply appreciate the microteaching experience and Eric Mazur's speech. It was wonderful to hear his talk and then spend an entire semester implementing his advice. Well done!

This site was created with funding courtesy of the The ExxonMobil Foundation and the following National Science Foundation-funded projects:

\begin{tabular}{|l|l|l}
\hline New Traditions (NT) & The National Institute for Science & The AAC\&U SENCER \\
\hline ModularChemistry (MC2) & $\underline{\text { Education }}$ & $\underline{\text { Institutes }}$ \\
\hline
\end{tabular}




\section{APPENDIX C: BEGINNING AND END-OF-SEMESTER SURVEY, FALL2003 \\ EPD654 Teaching Science and Engineering What do you already know? \\ code: (beginning of semester)}

Please use the following scale to let us know what you know about these teaching and learning issues.

$\begin{array}{lllllll}\text { Nothing } & 1 & 2 & 3 & 4 & 5 & \text { A great deal }\end{array}$

As you begin this professional development experience, identify what you already know about how to

Create an inclusive classroom environment to engage all students.

Be an active participant in a learning community.

Seek out connections among peers, faculty, and other learners both within and without the discipline (learning community).

Articulate your approach to teaching and learning.

Identify a concept, design and implement a teaching and learning plan, and reflect on the experience using a teaching-as-research approach.

Investigate, experience, and apply effective assessment, teaching, and learning practices.

View the role of assessment as central to effective teaching and learning.

Use ongoing formative assessment to continually gauge your students' learning and adjust your teaching accordingly.

Design a teaching and learning plan for a specific concept and a curriculum for a specific course.

Design, implement, and analyze a classroom assessment technique for the course.

Develop a deliberate, systematic, and reflective approach to teaching practices that advance the learning experiences and learning outcomes of students.

Use research as a basis for solving real-world teaching and learning issues.

Design your own research to explore teaching and learning issues of interest.

Use skills and tools to apply teaching-as-research to your classrooms.

Investigate research within and across STEM disciplines and education disciplines, including cognitive science 
Use peer reviews as an opportunity to give and receive feedback for improvement

Discuss teaching and learning issues with a peer, mentor, or others.

Reflect on and document teaching and learning experiences.

Seek out ways to improve your teaching in ways that meaningfully enhance student learning.

Please use the following scale to let us know your confidence level about these teaching and learning issues.

$\begin{array}{lllllll}\text { Not confident } & 1 & 2 & 3 & 4 & 5 & \text { Quite confident }\end{array}$

As you begin this professional development experience, identify the extent to which you are confident in your abilities to

Teach for student understanding

Design effective curriculum including objectives, methods, and assessment strategies

Investigate effective practices in higher education teaching and learning

Become change agents within your discipline

\section{Short Answer Question}

What does "teaching-as-research" mean to you? How can you imagine that such a concept might make a difference to you and your students?

\section{Demographic Information}

At what level are you in your graduate work? Masters First year of $\mathrm{PhD}$ Second year of $\mathrm{PhD}$ Last year of $\mathrm{PhD}$ Dissertator Post doc Faculty Academic staff Other (please explain)
What teaching experience do you have? No experience 1-2 semesters experience as a teaching assistant 3 or more semesters experience other:

What industrial experience do you have? No experience 1-2 years 
What else do you want us to know?

3 or more year

Dొ

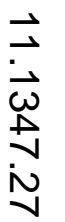


Now, what do you know?

(At the beginning of the semester, you responded to these questions titled, "What do you already know?" A few new demographic questions are added. We thank you in advance for your thoughtful responses.)

Please use the following scale to let us know what you know about these teaching and learning
issues.
Nothing
1
2
34
45
A great deal

At the end of this professional development experience, identify what you know about how to Create an inclusive classroom environment to engage all students.

Be an active participant in a learning community.

Seek out connections among peers, faculty, and other learners both within and without the discipline (learning community).

Articulate your approach to teaching and learning.

Identify a concept, design and implement a teaching and learning plan, and reflect on the experience using a teaching-as-research approach.

Investigate, experience, and apply effective assessment, teaching, and learning practices.

View the role of assessment as central to effective teaching and learning.

Use ongoing formative assessment to continually gauge your students' learning and adjust your teaching accordingly.

Design a teaching and learning plan for a specific concept and a curriculum for a specific course.

Design, implement, and analyze a classroom assessment technique for the course.

Develop a deliberate, systematic, and reflective approach to teaching practices that advance the learning experiences and learning outcomes of students.

Use research as a basis for solving real-world teaching and learning issues.

Design your own research to explore teaching and learning issues of interest.

Use skills and tools to apply teaching-as-research to your classrooms.

Investigate research within and across STEM disciplines and education disciplines, including cognitive science

Use peer reviews as an opportunity to give and receive feedback for improvement

Discuss teaching and learning issues with a peer, mentor, or others.

Reflect on and document teaching and learning experiences.

Seek out ways to improve your teaching in ways that meaningfully enhance student learning.

Please use the following scale to let us know your confidence level about these issues.

$\begin{array}{lllllll}\text { Not confident } & 1 & 2 & 3 & 4 & 5 & \text { Quite confident }\end{array}$

As you end this professional development experience, identify the extent to which you are $\underline{\text { confident in your abilities to }}$

Teach for student understanding

Design effective curriculum including objectives, methods, and assessment strategies

Investigate effective practices in higher education teaching and learning

Become change agents within your discipline 


\section{Short Answer Questions}

What does "teaching-as-research" mean to you? How can you imagine that such a concept might make a difference to you and your students?

Through your participation in this course and other Delta events/programs, did you feel like you were part of a bigger initiative of people on campus interested in improving their teaching and learning? Please describe.

Please check all other Delta events and programs that you attended this semester. Then, Please rank order the top three, using " 1 " to indicate that the event was of most value to you, "2" to indicate that that event was next most valuable, etc. If you did not attend any event/program listed, just leave it blank:

$\begin{array}{ll}\text { Monthly Roundtable (Richie Davidson in October) } & \text { ILSE general meetings/brownbags } \\ \text { Monthly Roundtable (John Wiley in December) } & \text { ILSE leadership meetings } \\ \text { Delta-sponsored lectures with Virginia Valian } & \text { Other Delta course }(s) \\ \text { Delta/CIRTL-sponsored lecture with Carl Wieman } & \text { CIRTL National Forum } \\ \text { Graduate student discussions with Virginia Valian } & \text { CCLE group } \\ \text { Graduate student discussions with Carl Wieman } & \text { Expeditionary Learning group } \\ \text { Workshop on NSF broader impact statements } & \end{array}$

Are you aware of future opportunities you have to be involved with Delta? If so, what do you know about? How might you continue your involvement?

\section{Demographic Information}

Gender:

Ethnicity:

Degree in Progress:
[] male [] female

[ ] Black, non-Hispanic

[ ] White, non-Hispanic

[ ] Hispanic

[ ] Asian or Pacific Islander

[ ] American Indian or Alaskan

[ ] Other

[ ] College of Letters \& Science

[ ] School of Human Ecology

[ ] School of Pharmacy

[ ] College of Engineering

[ ] Medical School

[ ] College of Agricultural \& Life Sciences

[ ] Institute for Environmental Studies

[ ] Other, please specify

[ ] Professional Degree

[ ] Master's Degree

[ ] Associate's Degree
[ ] Doctoral Degree

[ ] Bachelor's Degree

[ ] Certificate or Diploma 


\section{APPENDIX D: ASSESSMENT OF ACTIVITIES - Fall 2003 and Summer 2004}

The assessment of activities included the authentic assessments (curriculum, microteaching, teaching philosophy, and response papers), Student Assessment of Learning Gains (SALGains), peer-review focus groups on the last class day, and pre- and post-surveys. Results are described below in terms of learning gains and application.

\section{Learning/Gains in Knowledge}

Students learned basic knowledge, demonstrated conceptual change, and developed skills in teaching and learning according to instructor observations, results from the SALG survey, and, for fall, 2003, results from a comparison of a before and after survey.

Knowledge gains. Seventy percent indicated that, as a result of this course, they now understood their approach to teaching and learning, their strength and opportunities as a teacher and learner, teaching as research, the learning community concept, and the roles of assessment, according to the SALG results. (Q2.1-Q2.5)

Skill development. Ninety percent indicated that the course had added to their skills of critical reflection (Q3.2) and teaching (Q3.4) either a lot or a great deal (four and five points on a five-point scale). However, only sixty percent indicated that the course had added to their skills of peer reviews (Q3.1), curriculum design including objectives, learning activities, and assessment (Q3.3), and assessment (Q3.5).

Based on students' reflections on their micro-teaching experiences, it was clear that they developed significantly in their awareness of their students as learners. After watching videotapes of themselves, they realized not only surface features of their teaching style that needed improvement, but also deeper aspects of how they were teaching, how their students were understanding, and how to assess that understanding that needed refinement. Also, their ability to articulate their teaching and learning philosophy through written statements improved considerably from the first time they wrote a statement to the last.

Conceptual change. One hundred percent of students rated their ability to articulate their approach to teaching and learning as a four or five out of a maximum of five on the post-survey. Three categories: (1) ability to investigate, experience, and apply effective assessment, teaching, and learning techniques, (2) importance of seeking out ways to improve teaching that meaningfully enhance student learning, and (3) assessment as central to effective teaching and learning were rated by $93 \%$ of students as a four or five. Finally, $86 \%$ of students rated their ability to create an inclusive classroom environment, their ability to investigate effective practices in higher education, and their ability to design a teaching and learning plan for a specific concept and a curriculum for a specific course as a four or five.

\section{Application}

Applying their knowledge and skills in a collaborative learning environment, students designed microteaching experiences and drafted teaching and learning philosophies. Students in the fall course also designed a curriculum including a syllabus, three learning plans, an assessment plan, and a grading philosophy. Peer review was a critical component as students first worked independently to apply new knowledge, attitudes, and 
skills; then implemented desired processes and procedures; and finally analyzed and made adjustments in the continuous improvement of all the learning activities.

Teaching and learning philosophy: Early in the two-week course, students identified key principles to their own approach to teaching and learning. Working independently, they drafted their first teaching and learning philosophy. They received feedback from both the instructors and one peer. After continued discussions and learning experiences, they revised their philosophy. In most cases, considerable changes occurred. Not surprisingly, their revised philosophies were more succinct, descriptive, and complete with examples.

Micro-teaching: Students worked independently to design a learning plan to teach one concept from their discipline; they received feedback on the plan during an informal review session over lunch, and redesigned the plan before teaching "live" in small groups of four students with one of the three instructors also in each group. Given the short twoweek timeframe for the course, students were unable to teach in front of all the students; this was a disappointment for most students but a realistic solution to the challenge to incorporate a meaningful videotaped micro-teaching experience in the given timeframe.

The instructors did not keep copies of any student documents related to these learning experiences. However, SALG survey results indicated that all students thought the experiences helped them learn; feedback from the instructors and peers was particularly helpful in their application of knowledge and skills. As one student indicated, "[The instructor's] words to "trust yourself" as related to our Parker Palmer discussion flew by me unattended. However, hearing the same words in relation to my strengths and limitations after the microteaching had considerable meaning."

Teaching and learning philosophy: Similar to the summer experience, students wrote and peer-reviewed their approaches to teaching and learning. However, unlike in the summer experience, the instructors introduced the assignment in two different ways and are in the process of analyzing the experience to see if their approaches brought about different results. That is, they divided the class into two different groups; one group received three examples to examine and the other did not. These excerpts demonstrate participants' learning outcomes.

"I approach teaching with the same attitude I have used when doing mathematics and with the same attitude that I try to cultivate in my students. I ask myself many of the same questions. What is working? What is not working? What are some helpful ideas my colleagues have that I can use."

"In embracing the concepts of quality teaching and learning in my philosophy, I have defined four major objectives. They are 1) to develop students' habits of the mind that will enable them to adjust successfully to the changing world; 2) accept the responsibility for engaging the entire community in preparing life-long learners who are able to understand the world in which they live; 3) assist students to acquire the necessary skills to learn and succeed throughout their lifetime; and 
4) recognize, value, and build upon both the individual differences and the similarities among my students."

“Following are some strategies I use to understand learners' questions and how I use these questions to design and implement programs. They are grouped according to three objectives central to my teaching.

Developing responsive course objectives

Promoting confidence and "learning moments"

Building flexibility into courses, beginning with assessment"

\section{Micro-teaching:}

Micro-teaching provided participants an opportunity to identify a concept, design a teaching strategy (i.e., design the learning plan describing how you will present and assess a particular concept), teach, reflect, and re-design the plan for both student understanding and their continuous improvement. As confirmed in all assessment results, the micro-teaching experience consistently received the highest ratings. 